\title{
A study of two diuretic/potassium combinations in heart failure
}

\author{
M. Hussain, K. Walton, C. Davidson and D.B. Morgan \\ Birch Hill Hospital, Rochdale OL12 9QB and Department of Chemical Pathology, Leeds, UK.
}

\begin{abstract}
Summary: The effect of potassium supplements was studied in 28 patients taking long term frusemide (40-80 mg daily). Plasma potassium fell when supplements were stopped, and rose towards prior values on the potassium/frusemide combination, Diumide K. In a crossover study in 14 of these patients comparing equivalent doses of frusemide, Diumide $K$ (frusemide $40 \mathrm{mg}$, potassium $8 \mathrm{mmol}$ ), bumetanide, and Burinex K (bumetanide $0.5 \mathrm{mg}$, potassium $7.7 \mathrm{mmol}$ ) plasma potassium was lower on frusemide than on bumetanide. On Diumide $K$ and Burinex $K$ plasma potassium rose significantly but did not reach the levels on prior therapy. Small doses of potassium in combined formulations seem to be effective in countering the mild hypokalaemia caused by loop diuretics.
\end{abstract}

\section{Introduction}

Loop diuretics are the most effective and commonly prescribed drugs in heart failure, and are usually given with potassium supplements because of the risk of hypokalaemia. However a review of the literature suggested that, contrary to general opinion, the fall in serum potassium, and thus the frequency of hypokalaemia, was much less with the loop diuretics than with the thiazides (Morgan \& Davidson, 1980).

Nevertheless, a number of preparations have been developed where a loop diuretic is combined with either a potassium supplement or a potassium sparing duretic. We have compared the effect of two diuretics and diuretic/potassium combinations on plasma and red cell electrolytes in patients with stable heart failure. Frusemide and bumetanide were given without supplements and as combination therapy, Diumide $\mathrm{K}$ (frusemide $40 \mathrm{mg}$, potassium $8 \mathrm{mmol}$ ) and Burinex $\mathrm{K}$ (bumetanide $0.5 \mathrm{mg}$, potassium $7.7 \mathrm{mmol}$ ) per tablet in an open crossover study.

\section{Patients and methods}

Twenty-eight patients ( 14 male, 14 female) agreed to take part in the study. Eighteen patients had ischaemic heart disease, and ten patients valvular disease; their mean age was 62.5 y (range 39-75). All had been on a

M. Hussain, M.B.; K. Walton, M.B., M.R.C.P.; C. Davidson, M.B., M.R.C.P.; D. B. Morgan, M.D., M.R.C.Path. Correspondence: C. Davidson, Bateman Centre for Postgraduate Medical Studies, Birch Hill Hospital, Rochdale OL12 9QB.

Accepted: 30 May 1984 constant dose of frusemide for at least two months; one patient in the first study and one in the second were taking $80 \mathrm{mg} / \mathrm{d}$ and the rest were on $40 \mathrm{mg} / \mathrm{d}$. Twenty-seven patients were on potassium supplements $(8-32 \mathrm{mmol} / \mathrm{d}$, average $13 \mathrm{mmol} / \mathrm{d})$ and one on spironolactone. Seventeen patients were taking digoxin for atrial fibrillation.

After initial measurements, potassium supplements or spironolactone were stopped and the patients were allocated to their treatment groups. They were seen at two weekly intervals at the same time in the morning. At each visit their cardiac state was assessed, side effects were noted and an electrocardiogram (ECG) and a 30 second rhythm strip were taken. Blood was taken without venous occlusion or muscle pumping and separated within an hour. The plasma potassium was measured with an auto-analyser, and the erythrocyte potassium was measured by a technique described elsewhere (Morgan et al., 1980).

\section{Design of study}

The study was in two parts:

(a) Crossover comparison of frusemide and Diumide $\mathrm{K}$ : the first 14 patients ( 7 female) took frusemide or Diumide $\mathrm{K}$ in random order for periods of one month each;

(b) Crossover comparison of 4 preparations: the second 14 patients ( 7 female) were randomly allocated to frusemide or bumetanide and in order to avoid prolonged periods without supplements continued as follows:

bumetanide, $1 \mathrm{mg}$ - Burinex K (2 tablets) - 
frusemide, $40 \mathrm{mg}$ - Diumide K (1 tablet); OR frusemide, $40 \mathrm{mg}$ - Diumide K (1 tablet) - bumetanide, $1 \mathrm{mg}$ - Burinex K (2 tablets).

One patient was on $80 \mathrm{mg}$ frusemide and $2 \mathrm{mg}$ bumetanide and the equivalent doses of the combined preparations (see Ramsey et al., 1978).

The treatment periods were one month each, the total duration of the study being 16 weeks. Two patients were withdrawn after completing bumetanide - Burinex K only leaving 12 for comparison of all 4 preparations.

Criteria for withdrawal from the study included; clinical deterioration necessitating an increased dose of diuretic, digoxin toxicity, significant hypokalaemia (less than $3.0 \mathrm{mmol} / 1$ ) and side effects from the drugs. Statistical analysis was by two way analysis of variance and where appropriate, the paired ' $t$ ' test.

\section{Results}

\section{Clinical}

All patients completed the first part of the study but in the second 2 patients were withdrawn, both because of increasing heart failure. None of the patients developed clinical evidence of digoxin toxicity, and none had to be withdrawn because of hypokalaemia. There were no significant side effects from any of the preparations. Two patients died some months later, one after cardiac surgery and one from myocardial infarction.

\section{Electrocardiogram}

None of the patients developed any of the ECG features of hypokalaemia or digoxin toxicity. In 16 patients, 9 on digoxin, no ventricular ectopics were observed at any stage. In 5 patients, all on digoxin, ectopics occurred on only one occasion. Ventricular ectopics occurred on more than one occasion in 6 patients, 3 of whom were on digoxin. The occurrence of ectopics bore no relation to changes in plasma potassium or clinical state.

\section{Plasma and erythrocyte composition}

Comparison of frusemide alone and Diumide $K \mathrm{Com}-$ parative data were available from 14 patients from the first study and 12 from the second. There were no significant differences between these two groups and their results have been combined (Table I). There were no significant changes in weight or plasma and red cell electrolytes apart from potassium. Plasma potassium fell by $0.3 \mathrm{mmol} / 1$ when supplements were withdrawn and the patients continued on frusemide alone but rose on Diumide $\mathrm{K}$ towards the level on prior therapy $(P<0.001)$.

Comparison of bumetanide alone and Burinex $K$ (Table II) There were no significant changes in weight or plasma and red cell electrolytes apart from plasma potassium. On bumetanide alone plasma potassium was on average $0.23 \mathrm{mmol} / \mathrm{l}$ less than on prior therapy, and rose on Burinex $\mathrm{K}(P<0.05)$.

Comparison of four drugs Twelve patients (6 male, 6 female) completed a crossover comparison of all fou甲 drugs. There were again no significant changes of weight or plasma electrolytes apart from plasms potassium. The results (mean + s.d.) for plasma potassium were: prior therapy $3.82(0.32)$, frusemide 3.43 (0.31), Diumide K 3.67 (0.23), bumetanide 3.71 (0.31), Burinex K $3.75(0.28) \mathrm{mmol} / \mathrm{l}$. The plasma potassium on frusemide was significantly less than all other treatment periods $(P<0.01)$. In individual patients there was no significant correlation between the falls in plasma potassium on frusemide, and the smaller falls on bumetanide.

Table I Plasma and red cell electrolytes (mean \pm s.d.) in 26 patients completing a crossover comparison of frusemide alone and Diumide K. The plasma potassium was significantly lower on frusemide than on prior therapy or Diumide $K\left({ }^{* * *} P<0.001\right)$.

\begin{tabular}{|c|c|c|c|c|c|c|}
\hline & \multirow{2}{*}{$\begin{array}{l}\text { Weight } \\
\text { (kg) }\end{array}$} & \multirow[b]{2}{*}{$\mathrm{Na}^{+}$} & \multirow{2}{*}{$\begin{array}{c}\text { Plasma } \\
\text { mmol/l } \\
K^{+}\end{array}$} & \multirow[b]{2}{*}{ Urea } & \multicolumn{2}{|c|}{$\begin{array}{c}\text { Erythrocyte } \\
\text { mmol/l (washed) }\end{array}$} \\
\hline & & & & & $\mathrm{Na}^{+}(\mathrm{w})$ & $K^{+}(w)$ \\
\hline Prior therapy & $\begin{array}{l}65.46 \\
(16.72)\end{array}$ & $\begin{array}{r}140.3 \\
(1.7)\end{array}$ & $\begin{array}{l}3.88 \\
(0.32)\end{array}$ & $\begin{array}{l}6.37 \\
(1.7)\end{array}$ & $\begin{array}{c}7.62 \\
(1.04)\end{array}$ & $\begin{array}{l}86.0 \\
(1.2)\end{array}$ \\
\hline Frusemide & $\begin{array}{c}65.58 \\
(17.04)\end{array}$ & $\begin{array}{r}139.4 \\
(2.6)\end{array}$ & $\begin{array}{l}3.58 * * * \\
(0.36)\end{array}$ & $\begin{array}{l}6.38 \\
(1.57)\end{array}$ & $\begin{array}{l}8.03 \\
(1.41)\end{array}$ & $\begin{array}{c}87.0 \\
(1.4)\end{array}$ \\
\hline Diumide-K & $\begin{array}{l}66.2 \\
(16.77)\end{array}$ & $\begin{array}{r}139.4 \\
(1.7)\end{array}$ & $\begin{array}{c}3.84 \\
(0.36)\end{array}$ & $\begin{array}{c}6.98 \\
(2.26)\end{array}$ & $\begin{array}{l}7.76 \\
(1.17)\end{array}$ & $\begin{array}{l}86.8 \\
(2.1)\end{array}$ \\
\hline
\end{tabular}


Table II Plasma and red cell electrolytes (mean + s.d.) in 14 patients completing a crossover comparison of bumetanide and Burinex $\mathrm{K}$. The plasma potassium was significantly lower on bumetanide than on prior therapy $\left({ }^{*} P<0.05\right)$ or Burinex $\mathrm{K}$ $\left({ }^{*} P<0.05\right)$.

\begin{tabular}{lcccccc}
\hline & $\begin{array}{c}\text { Weight } \\
\mathrm{kg}\end{array}$ & $\mathrm{Na}$ & $\begin{array}{c}\text { Plasma } \\
\text { mmol/l } \\
\mathrm{K}^{+}\end{array}$ & Urea & $\mathrm{Na}^{+}(w)$ & $\mathrm{K}^{+}(w)$ \\
\hline Prior therapy & 65.64 & 140.0 & 3.90 & 6.27 & 7.76 & 86.8 \\
Bumetanide & $(17.70)$ & $(2.7)$ & $(0.29)$ & $(1.57)$ & $(1.17)$ & $(2.12)$ \\
& 65.36 & 138.8 & $3.67 *$ & 6.54 & 7.82 & 86.4 \\
Burinex K & $(17.87)$ & $(2.75)$ & $(0.33)$ & $(1.26)$ & $(1.55)$ & $(1.49)$ \\
& 65.03 & 138.1 & 3.81 & 6.95 & 7.81 & 87.8 \\
& $(17.95)$ & $(3.8)$ & $(0.30)$ & $(1.45)$ & $(1.40)$ & $(1.88)$ \\
\hline
\end{tabular}

Factors affecting plasma potassium during treatment: In most patients it was possible to compare the plasma potassium at the second and fourth week of each treatment period. There were no significant differences between the average values on the two visits but in individual patients there was considerable variation between the two values: mean difference $0.037 \mathrm{mmol} / 1$, s.d. $0.33 \mathrm{mmol} / 1, n=69$.

Despite this variation there did seem to be a significant difference between men and women, the fall in plasma potassium being greater in women (Table III). Indeed in men there were no significant differences between any of the treatments.

\section{Discussion}

This study suggests that potassium supplements can at least partly correct the fall in plasma potassium caused by frusemide and bumetanide. This finding is surprising considering the low doses of potassium used $(7-14 \mathrm{mmol} / \mathrm{d})$ when compared with the normal dietary intake of potassium $(50-150 \mathrm{mmol} / \mathrm{d})$. Nevertheless, the fall in plasma potassium when previous supplements were stopped $(0.23-0.30 \mathrm{mmol} / \mathrm{l})$ and the rise when potassium was given again $(0.14-0.26 \mathrm{mmol} / \mathrm{l})$, suggest that this is not a spurious result.

Table III Plasma potassium (mean \pm s.d.) during diuretic therapy: differences between the sexes $\left({ }^{*} P<0.05\right)$

\begin{tabular}{lccll}
\hline & $n$ & Prior therapy & Frusemide & Diumide-K \\
\hline Male & 13 & $3.79(0.25)$ & $3.71(0.29)$ & $4.01(0.36)$ \\
Female & 13 & $3.78(0.32)$ & $3.50(0.36)^{*}$ & $3.67(0.29)^{*}$ \\
\hline & $n$ & Prior therapy & Bumetanide & Burinex $K$ \\
Male & 7 & $3.94(0.37)$ & $3.74(0.21)$ & $3.91(0.32)$ \\
Female & 7 & $3.86(0.16)$ & $3.60(0.40)^{*}$ & $3.69(0.21)$ \\
\hline
\end{tabular}

Although loop diuretics have been widely used for more than twenty years, there is remarkably little information on their effect on serum (or plasma) potassium with or without potassium supplements. In early studies where frusemide was given without supplements serum potassium fell on average by $0.3 \mathrm{mmol} / \mathrm{l}$, compared to a fall of $0.6 \mathrm{mmol} / 1$ on thiazides (Morgan \& Davidson, 1980). Similar data for bumetanide were not available until recently, since most studies with this drug have included routine potassium supplements.

Two groups have reported the effect of bumetanide alone and compared it with frusemide. In a welldesigned crossover study Gabriel \& Baylor (1981) found that plasma potassium fell by $0.11 \mathrm{mmol} / 1$ on bumetanide compared to $0.24 \mathrm{mmol} / \mathrm{l}$ on frusemide. Yajnik et al. (1981) found more striking differences in a short parallel group study, the fall on bumetanide being $0.12 \mathrm{mmol} / 1$ and frusemide $0.81 \mathrm{mmol} / \mathrm{l}$. In our study there were small differences which again favoured bumetanide in the doses used. Short term balance studies have shown less urinary potassium loss after bumetanide than frusemide (Ramsay et al., 1978), and larger studies seem indicated to clarify the issue.

To our knowledge there are no previous studies of the effect of potassium supplements on the hypokalaemia caused by loop diuretics in short or long term therapy. Several reports (Singh \& Watt, 1976; Kubik et al., 1977; Murchison et al., 1975) with Burinex K and one (Lewis, 1979) with Diumide K show that plasma potassium is maintained over periods of up to six months, and by inference suggest that the dose of potassium included in the tablet is effective in long term treatment. This is supported by the findings of the present short term study. Although hypokalaemia was not entirely prevented, the number of patients with a plasma potassium less than $3.5 \mathrm{mmol} / \mathrm{l}$ was reduced from $30 \%$ to $12 \%$ by the change from frusemide to Diumide K. A similar but smaller effect was seen with bumetanide and Burinex $\mathrm{K}$. 
These findings conflict with the generally held view that potassium supplements are relatively ineffective. Evidence for this view comes from studies with thiazides rather than loop diuretics. In a community study (Krakauer \& Lauritzen, 1978) there was no significant difference in serum potassium between those taking and those not taking supplements; and in a small study Schwartz \& Schatz (1974) were unable to correct the serum potassium in some patients even with $96 \mathrm{mmol}$ potassium/d. In our review of the literature we found an increase in serum potassium of $0.32 \mathrm{mmol} / \mathrm{l}$ on supplements (mean dose $36 \mathrm{mmol} / \mathrm{d}$ ) which was less than the rise observed with potassium sparing diuretics (Morgan \& Davidson, 1980).

The apparent difference in the efficacy of potassium supplements during treatment with the thiazides and the loop diuretics cannot readily be explained. Jackson et al. (1982) have shown that there is a flat dose response curve, which implies that small doses of potassium are relatively more effective than high doses. As the fall in plasma potassium on loop diuretics is less than the thiazides the relatively small effect of supplements $(0.14-0.26 \mathrm{mmol} / \mathrm{l})$ may be sufficient to counter the hypokalaemia with loop diuretics where it cannot with thiazides. An alternative explanation is that in the combined preparations, Diumide $\mathrm{K}$ and Burinex $\mathrm{K}$, the diuretic component is incompletely absorbed and, therefore, has a smaller effect on plasma potassium. There was however no significant change in weight or other biochemical measurement to suggest this was the case.

There is still considerable debate about the clinical importance of mild hypokalaemia. One third of our patients on frusemide alone, and a smaller proportion on bumetanide, had a plasma potassium of $3.0-3.5 \mathrm{mmol} / \mathrm{l}$, but there were no clinical or ECG changes in these patients, even those taking digoxin. However, there are reports of increased ectopic

\section{References}

GABRIEL, R \& BAYLOR, P. (1981). Comparison of the chronic effects of bendrofluazide, bumetanide, and frusemide on plasma biochemical variables. Postgraduate Medical Journal, 57, 71.

HOLLAND, O.B., NIXON, J.V. \& KUHNERT, L. (1981). Diuretic induced ventricular ectopic activity. American Journal of Medicine, 70, 762.

HOLLIFIELD, J.W. \& SLATON, P.E. (1981). Thiazide diuretics, hypokalaemia and cardiac arrhythmias. Acta Medica Scandinavica. Suppl., 647, 67.

JACKSON, P.R., RAMSAY, L.E. \& WAKEFIELD, V. (1982). Relative potency of spironolactone, triamterene and potassium chloride in thiazide-induced hypokalaemia. British Journal of Clinical Pharmacology, 14, 257.

KRAKAUER, R. \& LAURITZEN, M. (1978). Diuretic therapy and hypokalaemia in geriatric out-patients. Danish Medical Bulletin, 25, 126. activity during continuous ECG monitoring with plasma potassium levels in this range (Steiness \& $\frac{2}{3}$ Olesen, 1976; Hollifield \& Slaton, 1981; Holland et al., $\stackrel{ه}{\&}$ 1981), and our observations were clearly limited in this $c$. respect.

One further point of interest lies in the greater fall in $\stackrel{\overrightarrow{\mathcal{O}}}{\stackrel{(}{+}}$ plasma potassium in women than in men when supplements were stopped. There is increasing 음 evidence that women are more susceptible to hypok- $\frac{\bar{D}}{D}$ alaema from any cause (Lawson et al., 1979; Morgan $\stackrel{\mathbb{Q}}{\varrho}$ \& Young, 1982). In a large community study Krak- ळ auer \& Lauritzen (1978) found that the serum potas- $\vec{\circ}$ sium during diuretic therapy was $4.1 \mathrm{mmol} / 1$ in men and $3.9 \mathrm{mmol} / 1$ in women, and in the recent report $\vec{\omega}$

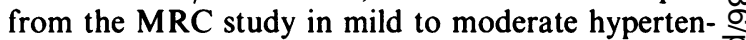
sion (1983) 12 of the 16 patients who developed severe 8 hypokalaemia on diuretics were women. The mechan- 3 . ism of this difference is unknown, but it is sufficiently $\stackrel{\sigma}{-}$ great to question the need for supplementation at all in $\underset{\supset}{\mathcal{V}}$ men, at least in the doses used in this study.

This study, taken with data from longer studies using Burinex $\mathrm{K}$ and Diumide $\mathrm{K}$, suggests that small 은 doses of potassium can be effective in reducing the hypokalaemia caused by loop diuretics. However, the $c$ fall in plasma potassium after loop diuretics is relative- $\frac{\vec{z}}{\overrightarrow{2}}$ ly small, and the need to correct it is still disputed. If potassium supplements are indicated, the advantage

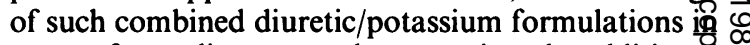
terms of compliance must be set against the additiona on cost of these drugs.

\section{Acknowledgements}

We are grateful to Napp Laboratories for financial support, Mrs J. Makin for red cell measurements, Mrs L. Long for secretarial help and $\mathrm{Mr} \mathrm{H}$. Williams for statistical advice.

KUBIK, M.M., BOWERS, E. \& UNDERWOOD, P.N. (1977). Comparison of separate versus simultaneous administration of potassium supplement with the diuretic bumetanide. Current Medical Research and Opinion, 5, 273.

LAWSON, D., HENRY, D., LOWE, J., GRAY, J. \& MORGAN, H.B. (1979). Severe hypokalaemia in hospital patients. Archives of Internal Medicine, 139, 978.

LEWIS, J.G. (1979). The effect on plasma potassium of a combined preparation of frusemide and slow-release potassium chloride (Diumide K Continus tablets). Journal of International Medical Research, 7, 354.

MRC Working Party on Mild to Moderate Hypertension (1983). Ventricular extrasystoles during thiazide treatment: substudy of MRC mild hypertension trial. British Medical Journal, 2, 1249.

MORGAN, D.B., CUMBERBATCH, M., COHN, S., SCOTT, D., GUNASUNTHARAM, T., DAVIDSON, C. \& CHAPMAN, C.

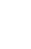


(1980). The erythrocyte sodium and potassium in patients treated with digoxin. British Journal of Clinical Pharmacology, 10, 127.

MORGAN, D.B. \& DAVIDSON, C. (1980). Hypokalaemia and diuretics: an analysis of publications. British Medical Journal, 1, 905.

MORGAN, D.B. \& YOUNG, R.M. (1982). Acute transient hypokalaemia: new interpretation of a common event. Lancet, ii, 751 .

MURCHISON, L.E., BEWSHER, P.D. \& SEYMOUR, R. (1975). Lack of effect of bumetanide on body potassium content in hypertension. British Journal of Clinical Pharmacology, 2, 87.

RAMSAY, L.E., MCINNES, G.T., HETTIARACHCHI, J., SHELTON, J. \& SCOTT, P. (1978). Bumetanide and frusemide: A comparison of dose-response curves in healthy men.
British Journal of Clinical Pharmacologi, 5, 243.

SCHWARTZ, A.B. \& SCHATZ, C.D. (1974). Dosage of potassium elixirs to correct thiazide induced hypokalaemia. Journal of the American Medical Association, 203, 702.

SINGH, B.B. \& WATT, D.A.L. (1976). Patient tolerance of a long term diuretic/potassium supplement therapy. Current Medical Research and Opinion, 4, 117.

STEINESS, E. \& OLESEN, K.H. (1976). Cardiac arrhythmias induced by hypokalaemia and potassium loss during maintenance digoxin therapy. British Heart Journal, 38, 167.

YAJNIK, V.H., KALAWADIA, S.V., PAREKH, B.H., KARELIA, L.S., PUROHIT, G.L., DOSHI, K.J. \& SAXENA. K. (1981). Bumetanide versus frusemide as a diuretic. Current Therapeutic Research, 29, 584. 